\title{
The effects of river flooding on dioxin and PCBs in beef
}

\section{Iain R. Lake ${ }^{a}$, Christopher D. Foxall ${ }^{a}$, Alwyn Fernandes ${ }^{b}$, Mervyn Lewis ${ }^{c}$, Oliver White ${ }^{c}$, David Mortimer ${ }^{\mathrm{d}}$,} Alan Dowding ${ }^{\mathrm{d}}$, Martin Rose ${ }^{\mathrm{b}, *}$

a School of Environmental Sciences, University of East Anglia, Norwich NR4 7TJ, UK

b The Food and Environment Research Agency (FERA), Sand Hutton, York Y041 1LZ, UK

c Askham Bryan College, Askham Bryan, York YO23 3FR, UK

d Food Standards Agency, Aviation House, 125 Kingsway, London WC2B 6NH, UK

\section{H I G H L I G H T S}

- Concentrations of dioxins and PCBs were higher in soil and grass from flood-prone farms.

- The beef samples from flood-prone farms had higher total TEQs.

- The first such controlled investigation.

- Flooding is a contaminant transfer mechanism to cattle raised on river catchments.

- Contamination is likely to be a result of legacy sources.
G R A P H I C A L A B S T R A C T

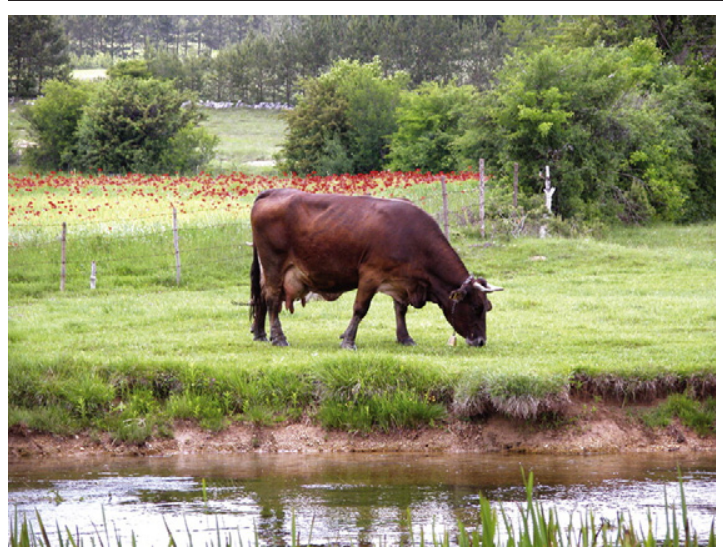

\section{A R T I C L E I N F O}

\section{Article history:}

Received 16 October 2013

Received in revised form 21 January 2014

Accepted 21 January 2014

Available online 14 February 2014

\section{Keywords:}

Dioxins

PCBs

Flooding

Beef

Food

Risk assessment

\begin{abstract}
A B S T R A C T
In 2008-2010, samples of meat from 40 beef cattle, along with grass, soil and commercial feed, taken from ten matched pairs of flood-prone and control farms, were analysed for PCDD/Fs and PCBs. Concentrations were higher in soil and grass from flood-prone farms. The beef samples from flood-prone farms had total TEQ levels about 20\% higher than on control farms. A majority of flood-prone farms (7/10) had higher median levels in beef than on the corresponding control farm. This first controlled investigation into PCDD/F and PCB contamination in beef produced on flood-prone land, presents robust evidence that flooding is a contaminant transfer mechanism to cattle raised on river catchments with a history of urbanisation and industrialisation. PCDD/F and PCB sources in these river systems are likely to be a result of the legacy of contamination from previous industrialisation, as well as more recent combustion activity or pollution events.
\end{abstract}

Crown Copyright (c) 2014 Published by Elsevier B.V. All rights reserved.

\footnotetext{
* Corresponding author. Tel.: + 441904 462655; fax: + 441904462111.

E-mail address: martin.rose@fera.gsi.gov.uk (M. Rose).
}

\section{Introduction}

Polychlorinated dibenzo-p-dioxins, polychlorinated dibenzofurans (PCDD/Fs, collectively referred to as "dioxins"), and polychlorinated biphenyls (PCBs) are widely recognised environmental and food contaminants. Historically, PCBs were widely used as cooling and 


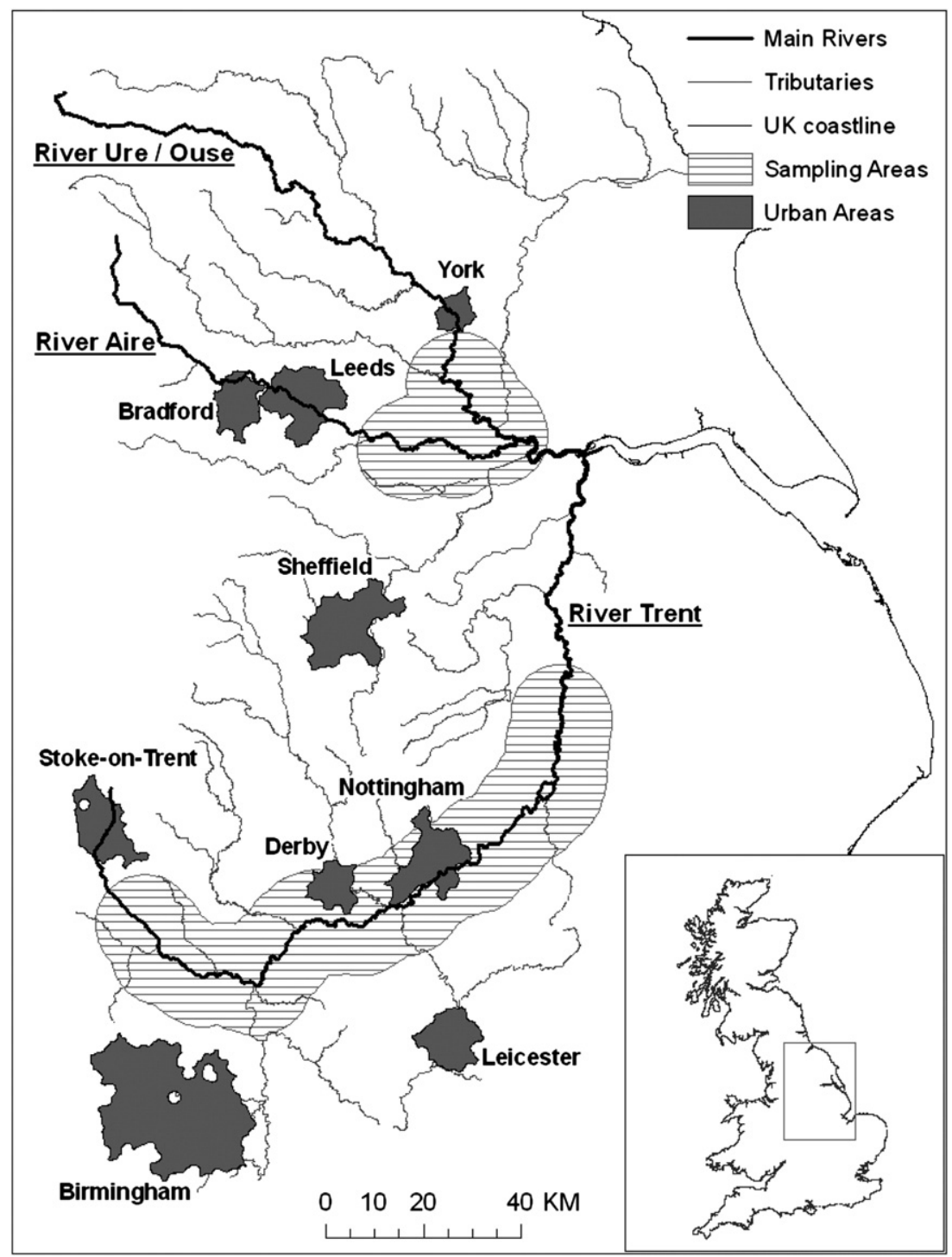

Fig. 1. The sampling areas and catchments of the Trent and the Aire/Ouse.

insulating fluids for industrial transformers and capacitors while PCDD/ Fs have never been produced intentionally and are formed as a byproduct of combustion activities or in the production of organochlorine chemicals (Schecter and Gasiewicz, 2003). Their ubiquitous presence has caused concern due to their environmental persistence, their bioaccumulation potential, and their toxic properties. The health effects associated with these compounds include immunotoxicity, carcinogenicity, and reproductive and developmental effects (Schecter and Gasiewicz, 2003).
In developed countries, the occurrence of $\mathrm{PCDD} / \mathrm{Fs}$ and $\mathrm{PCBs}$ is primarily a legacy of inadequate controls on emissions from sources of combustion, particularly waste incineration, and the historical use of PCBs. As PCBs have now been phased out, and industrial combustion emissions are tightly regulated, levels in the environment (Alcock and Jones, 1996; Schuster et al., 2011), food (Durand et al., 2008; Harrison et al., 1998) and humans (Alivernini et al., 2011; Lignell et al., 2009) are in decline. There is consequently a historical legacy of contamination due to the environmental persistence (half-lives measured in

Table 1

Categorised evidence used to assess the impact of flooding upon PCDD/F and PCB concentrations in meat.

\begin{tabular}{|c|c|}
\hline Category & Evidence \\
\hline $\begin{array}{l}\text { Strength of association between flooding and elevated contaminant levels. } \\
\text { Examined for hazard (soil and grass concentrations) and outcome (meat) }\end{array}$ & $\begin{array}{l}\text { - Contrasts in average contaminant concentrations between flood-prone and control farms } \\
\text { - Number of farm pairs where the flood-prone sample had higher average contaminant levels. } \\
\text { - Number of farm pairs where both flood-prone samples were higher than both control samples } \\
\text { (meat only). }\end{array}$ \\
\hline Consistency of association (hazard and outcome) & $\begin{array}{l}\text { - Whether contrasts between flood-prone and control farms were apparent on both river } \\
\text { systems. } \\
\text { - If distinct congener profiles exists on grass and soil from flood-prone farms, in comparison to } \\
\text { control farms, then these should also be evident in meat produced on such farms. }\end{array}$ \\
\hline Alternative explanations & $\begin{array}{l}\text { - Commercial feed contrasts between flood-prone and control farms } \\
\text { - Are there logical explanations for unexpected concentrations in observed data? }\end{array}$ \\
\hline
\end{tabular}


a) Meat

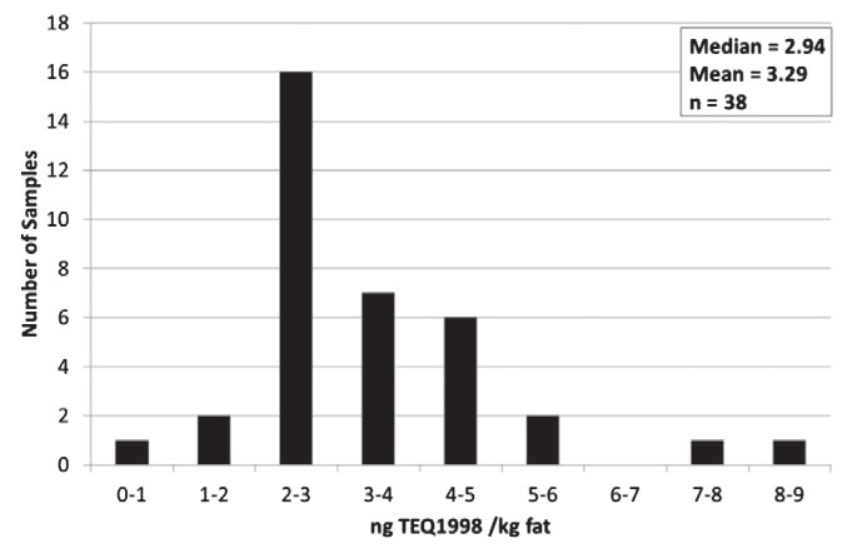

c) Grass

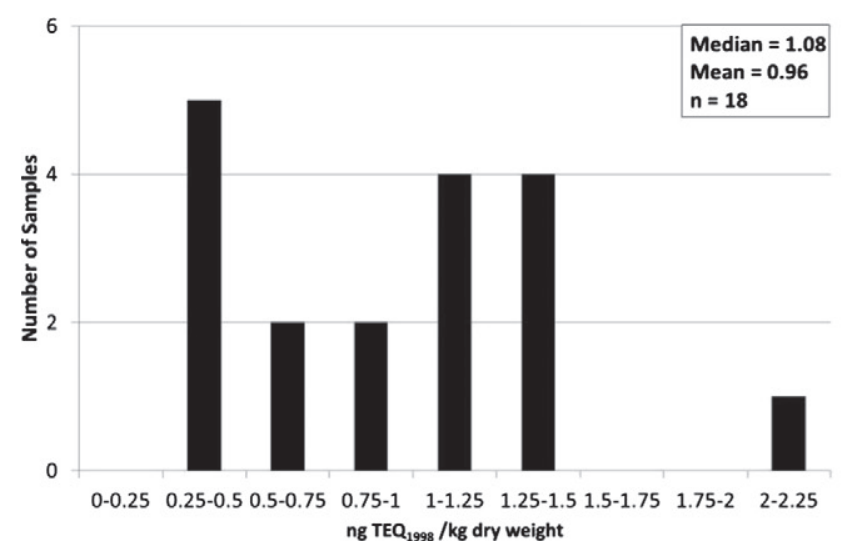

b) Soil

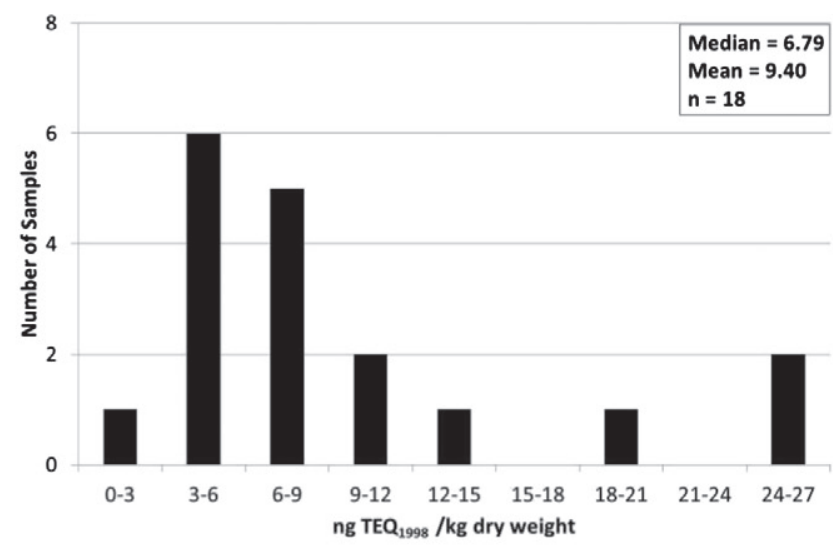

d) Commercial feed

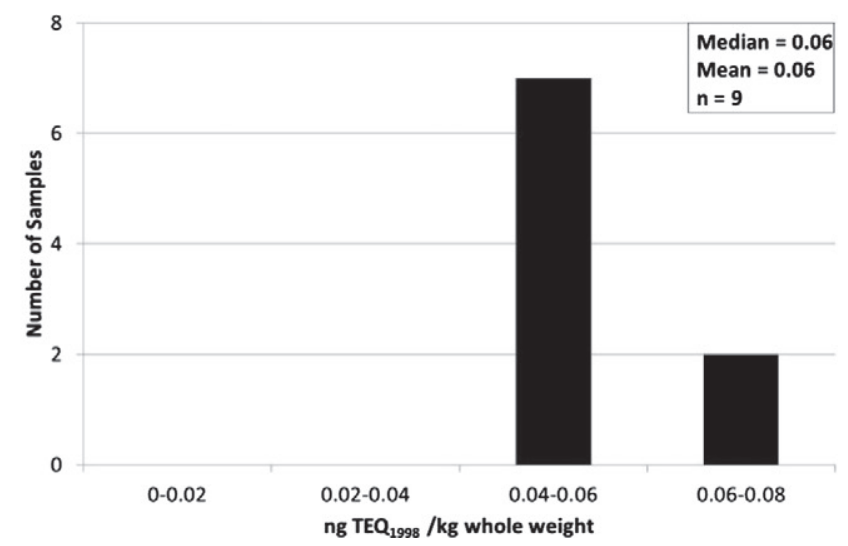

Fig. 2. Distribution of total TEQ for meat (a), soil (b), grass (c) and commercial feed samples (d).

decades) of many of these compounds. In less developed countries, the situation is different, with rapid industrialisation leading to increasing emissions which are only now starting to be controlled (Zhao et al., 2011). Studies have indicated that in some of these countries, PCDD/F and PCBs levels in human tissue are now similar to those in European populations (Shen et al., 2009). There is also evidence that in these less developed countries, concentrations of PCDD/Fs and PCBs are still rising in humans (Sun et al., 2011).

To protect public health in all countries, it is essential to understand the mechanisms through which PCDD/F and PCBs in the environment can transfer to humans. The major route of transfer for most of the population where there is no history of occupational exposure, is through food, which is estimated to account for around $90 \%$ of body burden (Liem et al., 2000). This is due to the propensity of PCDD/Fs and PCBs to bioaccumulate in fatty foods such as fish, meat, dairy products, and eggs (Schecter and Gasiewicz, 2003). These foods have thus been shown to be major contributors to dietary intake (Fernandes et al., 2004; Food Standards Agency, 2003; Startin and Rose, 2003). $\mathrm{PCDD} / \mathrm{Fs}$ and PCBs can contaminate foodstuffs through several pathways, especially atmospheric deposition. It has been demonstrated that concentrations of these contaminants are often higher in produce from farms close to urban areas or industrial facilities, e.g. milk (Ball et al., 1993; Ministry of Agriculture Fisheries and Food, 1997). In addition to aerial deposition, transfer through river systems may also be important as sediment in river systems can serve as a sink for PCDD/Fs and PCBs and then provide a long term source of release (Fattore et al., 2002). Studies of PCDD/F and PCB loadings in the sediments of rivers worldwide have confirmed this (Fattore et al., 2002;
Zhang et al., 2008). Flooding of land by river water carrying PCDD/F and PCB contaminated sediment has been demonstrated to be an important source of localized contamination (Lake et al., 2005), providing another pathway for transfer to the human food chain. Milk produced on flood-prone land on industrial river catchments has elevated PCDD/Fs and PCBs (Lake et al., 2005). This study represents the first controlled investigation into potential contaminant transfer to beef cattle grazing on flooded pastures. It explores whether overbank flooding of grazing land might influence the concentration of PCDD/Fs and PCBs in animals reared using conventional animal husbandry techniques. Beef products, specifically carcass meat, are important commodities in the diet of the UK and many countries. The aims of the study were:

1. to establish whether flooding has an impact upon PCDD/F and PCB concentrations in meat of beef cattle

2. to provide supporting evidence by analysing matched samples of soil, grass and commercial feed samples from each farm.

\section{Materials and methods}

\subsection{Study area}

The study focused on the Trent and the Aire/Ouse river systems in central England. The locations of these are presented in Fig. 1 and both flow through substantial urban and industrial areas. The figure also shows that there are many rural areas within these catchments. Previous research has demonstrated elevated PCDD/Fs and PCBs on 
Table 2

Comparisons of total TEQ in meat, soil, grass and commercial feed by river system and type of site for matched pairs of farms.

\begin{tabular}{|c|c|c|c|c|c|c|c|c|c|c|}
\hline \multirow[b]{4}{*}{ Sample } & \multicolumn{4}{|l|}{ Meat } & \multirow{2}{*}{\multicolumn{2}{|c|}{$\begin{array}{l}\text { Soil } \\
\text { Total TEQ } \\
\left.\text { (ngTEQ }_{1998} / \mathrm{kg} \text { dry } w t\right)\end{array}$}} & \multirow{2}{*}{\multicolumn{2}{|c|}{$\begin{array}{l}\text { Grass } \\
\text { Total TEQ } \\
\text { (ng TEQ } 1998 / \text { kg dry wt) }\end{array}$}} & \multirow{2}{*}{\multicolumn{2}{|c|}{$\begin{array}{l}\text { Commercial feed } \\
\text { Total TEQ } \\
\text { (ng TEQ } \\
\text { 1998 } / \text { kg whole wt })\end{array}$}} \\
\hline & \multicolumn{4}{|c|}{ Total TEQ (ng TEQ ${ }_{1998} / \mathrm{kg}$ fat) } & & & & & & \\
\hline & \multicolumn{2}{|c|}{ Flood-prone } & \multicolumn{2}{|l|}{ Control } & \multirow[t]{2}{*}{ Flood-prone } & \multirow[t]{2}{*}{ Control } & \multirow[t]{2}{*}{ Flood-prone } & \multirow[t]{2}{*}{ Control } & \multirow[t]{2}{*}{ Flood-prone } & \multirow[t]{2}{*}{ Control } \\
\hline & $\begin{array}{l}\text { Sample } 1 \\
\text { Sample } 2\end{array}$ & Farm Median & $\begin{array}{l}\text { Sample } 1 \\
\text { Sample } 2\end{array}$ & Farm Median & & & & & & \\
\hline \multicolumn{11}{|l|}{ Trent } \\
\hline Pair 1 & $\begin{array}{l}4.40 \\
2.58\end{array}$ & 3.49 & $\begin{array}{l}2.89 \\
2.62\end{array}$ & 2.76 & 26.55 & 2.66 & 1.29 & 0.32 & - & 0.06 \\
\hline Pair 2 & $\begin{array}{l}2.21 \\
1.91\end{array}$ & 2.06 & $\begin{array}{l}2.22 \\
2.57\end{array}$ & 2.40 & 13.37 & 9.10 & 0.52 & 0.27 & $\ddagger$ & $\ddagger$ \\
\hline Pair 3 & $\begin{array}{l}2.76 \\
3.04\end{array}$ & 2.90 & $\begin{array}{l}2.65 \\
2.23\end{array}$ & 2.44 & 5.71 & 6.13 & 0.90 & 0.26 & $\ddagger$ & $\ddagger$ \\
\hline Pair 4 & $\begin{array}{l}2.38 \\
2.35\end{array}$ & 2.37 & $\begin{array}{l}1.51 \\
2.00\end{array}$ & 1.76 & 25.09 & 7.36 & 1.49 & 0.32 & $\ddagger$ & 0.06 \\
\hline Pair 5 & $\begin{array}{l}4.77 \\
2.64\end{array}$ & 3.71 & $\begin{array}{l}1.51^{\&} \\
2.00^{\&}\end{array}$ & $1.76^{\&}$ & $\ddagger$ & & $\ddagger$ & & 0.06 & $\ddagger$ \\
\hline $\begin{array}{l}\text { Median } \\
\text { Aire/Ouse }\end{array}$ & 2.61 & & 2.40 & & 19.23 & 6.75 & 1.10 & 0.30 & 0.06 & 0.06 \\
\hline Pair 1 & $\begin{array}{l}3.43 \\
4.01\end{array}$ & 3.72 & $\begin{array}{l}8.85 \\
7.61\end{array}$ & 8.23 & 6.22 & 3.21 & 1.22 & 1.20 & 0.07 & - \\
\hline Pair 2 & $\begin{array}{l}4.76 \\
4.50\end{array}$ & 4.63 & $\begin{array}{l}4.00 \\
3.36\end{array}$ & 3.68 & 9.22 & 4.84 & 0.51 & 1.37 & - & - \\
\hline Pair 3 & $\begin{array}{l}2.98 \\
3.89\end{array}$ & 3.44 & $\begin{array}{l}3.60 \\
3.93\end{array}$ & 3.77 & 19.27 & 5.51 & 2.41 & 0.96 & 0.06 & 0.07 \\
\hline Pair 4 & $\begin{array}{l}5.48 \\
3.92\end{array}$ & 4.70 & $\begin{array}{l}1.73 \\
2.00\end{array}$ & 1.87 & 7.55 & 4.08 & 0.49 & 1.20 & 0.06 & 0.06 \\
\hline Pair 5 & $\begin{array}{l}5.15 \\
2.99\end{array}$ & 4.07 & $\begin{array}{l}0.90 \\
0.31\end{array}$ & 0.61 & 7.96 & 5.41 & 1.37 & 1.25 & 0.06 & 0.06 \\
\hline Median & 3.97 & & 3.48 & & 7.96 & 4.84 & 1.22 & 1.20 & 0.06 & 0.06 \\
\hline
\end{tabular}

flood-prone pasture at farms next to the river Trent (Lake et al., 2005). No comparable reports have been published on the Aire/Ouse river system. Maps of beef farm distributions and flood history along the two river systems were used to identify beef farms where a substantial proportion of the land regularly flooded. For each flood-prone farm, a nearby farm that was not subject to flooding, but which would be subject to similar amounts of aerial deposition of PCDD/Fs and PCBs (e.g. similar proximity to major roads) was selected as a control. The application of sewage sludge to land is a potential source of $\mathrm{PCDD} / \mathrm{Fs}$ and PCBs, but none of these farms had received any sewage sludge over the last 20 years. The comparison of PCDD/Fs and PCBs between food produced on these pairs of farms provides the strongest evidence with which to examine the impact of flooding.

Ten farms on the River Trent ( 5 flood-prone/control pairs) satisfied these criteria and consented to take part in the study. In the event, one of the control farms was unable to provide any animals. The farm pairs selected encompassed locations on the upper, middle and lower reaches of the river. A further 10 farms (5 flood-prone/control pairs) on the middle-lower reaches of the Aire/Ouse river system agreed to take part, resulting in a total of 19 farms. From each of these farms, 2 beef cattle were selected from the herd and immediately transported to the abattoir for slaughter. The animals from the Trent and Aire/Ouse farms were collected during October-December 2008 and October 2010-February 2011 (extended due to poor weather) respectively. Samples of meat (muscle tissue) were taken from each animal. Processing of carcases at the abattoir was scrutinized to prevent cross contamination and to ensure sample integrity. The animals from which samples were taken were not market-ready, and beef cattle would normally be subject to an indoor finishing period during which they would be fed silage and commercial feed before eventual slaughter.

\subsection{Samples collected}

To provide supporting information for any trends emerging from the meat data, sources of dietary input to the beef cattle were also collected from all 19 farms during the same period that the animals themselves were collected. Grass is consumed by cattle while they are outdoors and soil is consumed inadvertently - while foraging. Commercial feed is provided to the cattle during the period they are indoors and silage is often given to cattle as pasture starts to decline in the autumn. Soil and grass samples were collected from fields regularly grazed by the herd using previous published methods (Lake et al., 2005). In the case of flood-prone farms, samples were taken from locations with a known history of flooding.

\subsection{Analysis and interpretation of data}

PCDD/F and PCB concentrations were determined using accredited methods (UKAS; ISO 17025 standard). All analyses were based on the seventeen 2,3,7,8-Cl substituted PCDD/F congeners, four non-ortho PCBs $(77,81,126$, and 129) and twenty-one ortho congeners $(18,28$, $31,47,49,51,52,99,101,105,114,118,123,128,138,153,156,157$, 167,180 , and 189). TEQ values were calculated using WHO-1998 TEFs (van den Berg et al., 1998) to facilitate comparison with previously published data. Concentrations are reported as upper-bound total TEQs incorporating PCDD/F, ortho and non-ortho PCB concentrations. 

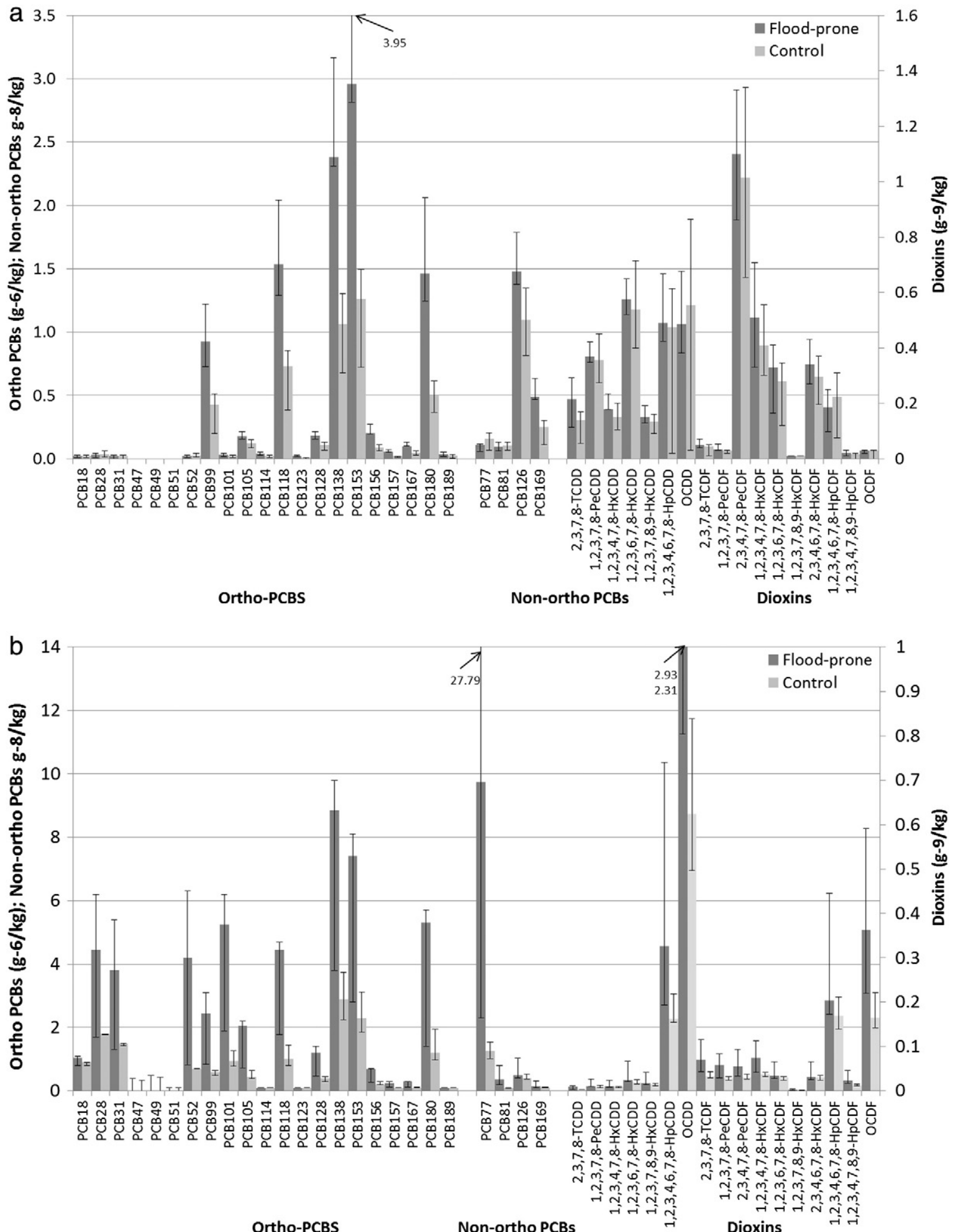

Fig. 3. Median (+-inter-quartile range) congener profiles for meat (a), soil (b) and grass (c) subdivided by type of site.

Upper-bound PCDD/F concentrations are also reported. Further details on the concentration of individual congeners are presented elsewhere (Lake et al., 2012). In total, 83 samples ( 38 meat, 18 soil, 18 grass and 9 commercial feed) were analysed for PCDD/Fs and PCBs. As per the usual convention, and to allow easy comparison with other literature data, the meat (muscle tissue) data are presented throughout on a fat weight basis; grass and soil on a dry weight basis; feed on a whole weight basis. Extensive quality control and assurance measures for all analytes were undertaken (see Lake et al., 2005).

These data were analysed using conventional statistical analysis (See Supplementary Material 1) but due to the relatively small numbers of samples analysed in this study, very pronounced differences would be required between flood-prone and control sites to achieve statistically significant contrasts. To overcome these limitations, and to provide a 
Table 3

Weight of evidence table examining the impact of river flooding upon PCDD/F and PCB concentrations in meat.

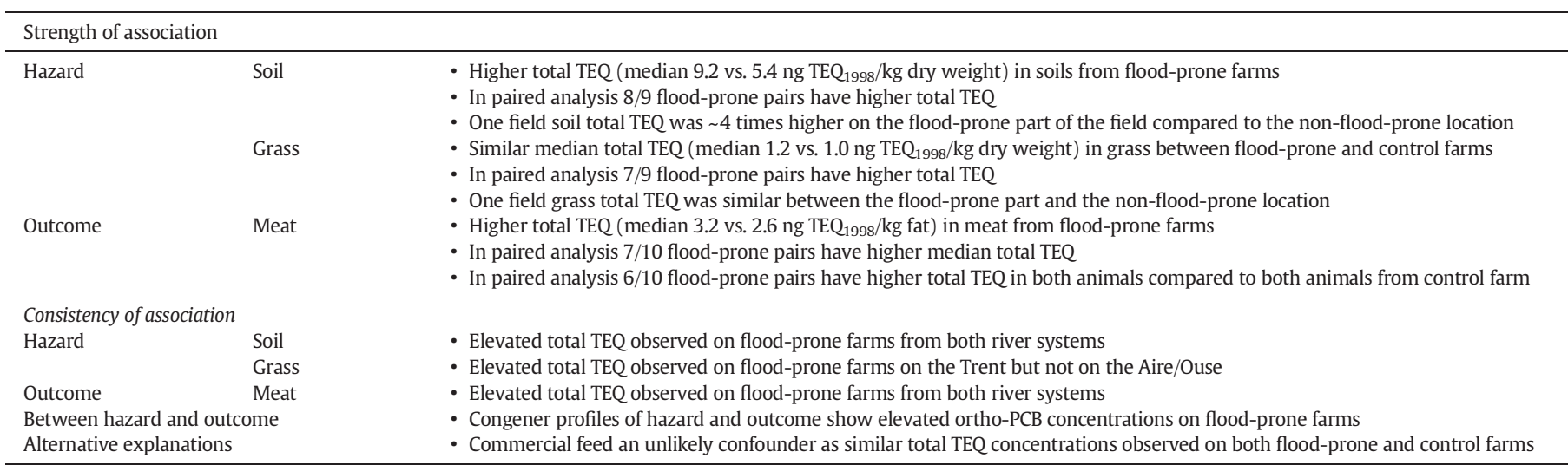

more holistic overview of the data, our preferred method of analysis is using a weights of evidence table (Linkov et al., 2009). Such integrative approaches are used widely (Landis and Bryant, 2010; Swaen and van Amelsvoort, 2009). In this table all the evidence on flood-prone vs. control contrasts were listed and categorised using commonly utilised causation criteria (Hill, 1965) as indicated in Table 1. In this table the "Strength of Association" evidence is listed in order of increasing strength as the contrasts in the paired analysis are stronger than the average differences between all flood-prone and control farms.

\section{Results}

The distributions of total TEQ (sum of PCDD/F and dioxin-like PCB TEQ) in meat, soil, grass and commercial feed are presented in Fig. 2. The meat data (Fig. 2a) demonstrated large variations in total TEQ concentrations with median levels of 2.94 (ng TEQ/ $\mathrm{kg}$ fat) and range of $0.31-8.85$ (ng TEQ $/ \mathrm{kg}$ fat). The median value was less than the mean indicating that the distribution had a long right tail with a majority of lower values and a few higher ones. The soil data (Fig. 2b) also presents a skewed distribution with a median value of 6.79 (ng TEQ/ kg dry weight) and a large range (2.66-19.27 ng TEQ/kg dry weight). By contrast the grass data (Fig. 2c) had lower total TEQ (median $1.08 \mathrm{ng} \mathrm{TEQ} / \mathrm{kg}$ dry weight) and a more restricted range (0.26-2.41 ng $\mathrm{TEQ} / \mathrm{kg}$ dry weight). The commercial feed samples had low amounts of total TEQ (median $0.06 \mathrm{ng} \mathrm{TEQ} / \mathrm{kg}$ whole weight ) and a narrow range (0.06-0.07 ng TEQ/kg whole weight).

To provide further information on the total TEQs and to allow comparisons between flood-prone and control sites, the meat data for individual animals are presented for matched pairs of flood-prone and control farms in Table 2. Data is presented for the individual animals alongside the median value for each farm.

Table 2 reveals moderate differences in the concentrations found in meat between the two animals collected from each farm (mean difference 0.77 , standard deviation $0.67 \mathrm{ng}$ TEQ/kg fat). Although there is generally good agreement between pairs of animals from the same farm, there are sometimes considerable variations (e.g. Aire/ Ouse flood-prone pair 5). Given the identical husbandry to which each animal was exposed, the differences are likely to be due to physiological variations. Total TEQ on Aire/Ouse control farm pair 1 appear unusually high and both animals have total TEQ 50\% greater than any other sample. Table 2 also demonstrates median total TEQ concentrations in meat from the Aire/Ouse were around 50\% higher than those on the Trent for both flood-prone and control farms.

In terms of flooding, on both river systems, median total TEQs in meat are higher in samples from flood-prone farms than their control comparators (Trent: 2.61 vs. 2.40 ng TEQ/kg fat; Aire/Ouse: 3.97 vs. $3.48 \mathrm{ng} \mathrm{TEQ} / \mathrm{kg}$ fat). A more robust analysis compares the median total TEQ for the two animals from each flood-prone farm to the median total TEQ of the two animals from its matched control farm. Seven from 10 flood-prone farms have higher median total TEQ levels in meat in comparison to their matched control farm. More robust still, for 6 of the 10 pairs, the total TEQ levels in both animals from each of the flood-prone farms were higher than for both animals from the matched control farms.

To provide supporting evidence for the trends in meat, soil, grass and commercial feed, samples were collected and analysed for total TEQ (Table 2). This shows that total TEQ in soil is generally higher on the Trent than on the Aire/Ouse river system. In terms of flooding on both river systems, median soil concentrations are higher on flood-prone farms. Stronger evidence emerges when the individual flood-prone/ control pairs are examined and 8/9 have higher concentrations on flood-prone farms in comparison to their controls. A further way to examine the impact of flooding is to compare samples of soil simultaneously collected from flood-prone and non-flood-prone sites situated in the same field. Two such samples were collected from the flood-prone, pair 1 site on the Aire/Ouse during the second sampling phase. The total TEQ were 4 times higher on the flood-prone part of the field ( $6.22 \mathrm{vs} .1 .41 \mathrm{ng} \mathrm{TEQ} / \mathrm{kg}$ dry weight) providing further evidence that flooding transfers PCDD/Fs and PCBs to the land. Total TEQ for grass samples provides a poorer indication of the impact of over-bank flooding, as such samples would be expected to be more subject to short-term factors such as precipitation or air temperature. Nonetheless Table 2 indicates that on both river systems median total TEQ was higher on flood-prone farms. A comparison of farm pairs provides more robust evidence of this and 7/9 farm pairs have higher total TEQ on grass from flood-prone farms. On the site where samples were collected from flood-prone and non-flood-prone sites situated in the same field grass concentrations were marginally higher on the floodprone part of the field ( $1.22 \mathrm{vs.1.14} \mathrm{ng}$ TEQ/kg dry weight). Commercial feed was fed to some of the cattle towards the end of their period outdoors to compensate for declining quantities of grass. Some cattle on the Aire/Ouse would have been fed greater amounts of commercial feed as the collection of animals was delayed until the beginning of February due to poor weather. Table 2 indicates that nearly all commercial feed samples had identical total TEQ and there was no evidence of elevated levels on flood-prone farms.

To provide further information on the impact of flooding Fig. 3(a)-(c) presents the median congener profile for all meat, soil and grass samples subdivided between flood-prone and control farms. An examination of the ortho-PCB profiles indicates that meat, soil and grass samples from flood-prone farms generally have higher concentrations than the corresponding samples from control farms. A similar differential is not apparent for non-ortho PCBs or PCDD/ Fs. It is worth noting the strong similarity in ortho-PCB profiles between soil and grass, suggesting a common source of contamination. The virtual absence of the lower chlorinated PCB congeners in 
meat samples, despite their prominence in soil and grass, is consistent with PCB congeners 18, 25, 31, 52 and 101 being metabolised in cows (Thomas et al., 1999).

The beef samples taken in this study were not from market ready animals, and therefore regulatory limits do not apply. But it is interesting to note that on both river systems, Table 2 shows that several of the meat samples would have been above the action levels or maximum levels under EU regulations applicable at the time of sampling. There is an on-going UK Food Standards Agency project looking at contaminants including dioxins and PCBs in matched meat and offal from cattle of different ages to investigate whether or not there could be a problem with compliance with action levels and/or maximum levels in meat or offal that is destined for the food chain.

In January 2012, revised values for maximum levels and action levels for PCDD/Fs and PCBs for a range of foodstuffs based on the WHO-2005 TEF (van den Berg et al., 2006) values for PCDD/Fs and dioxin like PCBs were adopted within the EU (European Commission, 2011a, 2011b). The concentrations of PCDD/Fs and dioxin-like PCBs shown in Table 2 have been recalculated (see supplementary material 2) using the 2005 TEFs and this results in a mean reduction in total TEQ in meat of $11.9 \%$ (standard deviation 1.54\%).

The low numbers of samples and sample pairs analysed in this study make the data less amenable to formal statistical analysis. Therefore, a weight of evidence table was constructed in Table 3. A statistical analysis is presented in Supplementary Material 1.

\section{Discussion and conclusion}

Most of the evidence in Table 2 suggests that river flooding leads to elevated PCDD/F and PCB levels in meat. PCDD/F and PCB levels were higher in soil from flood prone farms and most farm pairs had higher soil total TEQ on the flood-prone farm. This result was consistent between river systems. Furthermore, on one field soil total TEQ was higher on the flood-prone part of the field in comparison to a location on the field that was not flood-prone. Comparable results for grass were not as strong but this is to be expected as the PCDD/F and PCB concentrations in grass will be more subject than soil to short-term influences such as rainfall or air temperature. Together the grass, but especially soil results, indicate that a potential for elevated PCDD/F and PCB levels in meat exists. This is in agreement with previous research (Lake et al., 2005, 2011). Cattle consume grass directly as forage, and in the UK summer this will be the major constituent of their diet. Therefore, elevated PCDD/F and PCB concentrations in grass present a clear pathway for these contaminants into beef. The situation with soil is different as cattle generally only consume soil inadvertently. The few summer estimates of soil ingestion that exist suggest that soil constitutes a very small proportion (3.2-3.4\% dry matter) of dietary intake (Healey, 1968; Thornton and Abrahams, 1983). In this study total TEQ levels in soils were on average nearly 13 times higher than grass from the same location. Therefore, even small amounts of soil ingestion have the potential to affect PCDD/F and PCB concentrations in beef.

Direct evidence of the impact of flooding on PCDD/F and PCB concentrations emerges from the analysis of the meat samples. These suggest that this potential for elevated $\mathrm{PCDD} / \mathrm{F}$ and $\mathrm{PCB}$ concentrations was realised, as meat samples from flood-prone farms had total TEQ levels that were around $20 \%$ higher than those from flood prone farms. The strongest evidence emerges from the paired analysis and most flood-prone farms had higher median levels than the matched control farms. Furthermore in most of these farms, both meat samples were higher than the corresponding 2 samples from the control farm. This result was consistent between the two river systems. The congener profiles of beef produced on flood-prone farms was similar to the congener profiles of soil and grass from flood-prone sites with elevated ortho-PCB concentrations, suggesting soil and grass as the source of the elevated levels in beef.
Alternative explanations were examined. Commercial feed samples were analysed and found to have nearly identical PCDD/F and PCB concentrations for both types of farms. One apparent anomaly in the data collected was from control farm pair 1 on the Aire/Ouse. Total TEQ concentrations in meat were 1.5 times higher than any other sample. However, a detailed examination of the animal husbandry data for this farm revealed two hypotheses for the elevated total TEQ. Firstly the two beef cattle were notably older than for other farms ( 26 and 31 months versus an average age of 11 months on all other farms). There is evidence that the body burden of PCDD/F and PCB increases with age in some mammals (Lorber et al., 1997). The second hypothesis is based on the observation that both animals were noted at slaughter as being somewhat emaciated. The mobilisation of fat within the animals may have contributed to elevated total TEQ. Elevated levels of PCDD/Fs and PCBs have been observed in other animals during fasting (Bustnes et al., 2010; Debier et al., 2006). Based upon all the evidence presented, we conclude that in river systems with a history of industrial activity river flooding transfers PCDD/Fs and PCBs to meat in beef cattle raised on the flood plains.

To collect stronger evidence for the impact of flooding upon PCDD/F and PCB concentrations in meat it would have been useful to examine the impact of specific flooding events upon concentrations in meat but previous research has indicated that the impact of flooding is cumulative in nature and not normally related to single events (Foxall et al., 2004). Experimental approaches such as moving beef onto and off flooded pastures would provide further supportive evidence but these were not feasible in this study of working beef farms. Indicating a dose-response relationship between exposure to flooded pasture and concentrations of PCDD/F and PCBs would have provided further useful evidence. However, given that each of the farms in this study flooded to differing extents (9-93\%, mean 50\%), for different durations and that beef cattle would have moved around the farm in a nonrandom way, determining a "dose" for each farm was infeasible. Cattle on flood-prone farms spend much of their time on land that does not flood. This suggests that the dose of PCDD/Fs and PCBs received on flood-prone land is not entirely masked by the time spend on nonflood prone sites. While the cattle are outdoors they are not usually provided with commercial feed and they forage almost exclusively on pasture. Therefore, commercial feed does not provide the masking effect suggested on studies of other foodstuffs (Lake et al., 2011).

The aim of this study was to examine the impact of river flooding upon PCDD/F and PCB in beef. However, it was also observed that $\mathrm{PCDD} / \mathrm{F}$ and $\mathrm{PCB}$ concentrations in beef were above those reported by the latest UK Total Diet Study (mean 3.3 vs. 0.9 ng TEQ/kg fat) (Food Standards Agency, 2003). This was anticipated because both river systems were selected on the basis that their catchments contained substantial urban and industrial areas. Commercial feed was discounted as a source, as concentrations in feed were similar to those reported in other UK studies (Fernandes et al., 2006). The elevated levels were such that several of the meat samples would have been above the action levels or maximum levels under EU regulations applicable at the time of sampling. It is important to recognise that these samples would probably not have entered the food chain at this stage, because under current husbandry practice, after being taken indoors the cattle would typically have undertaken a finishing-off period. This usually consists of around 6 months indoors being fed commercial feed as well as silage (usually from the farm). Our own results indicated relatively low levels of total TEQ in commercial feed in comparison to the environmental (soil and grass) samples. There is limited evidence on the half lives of PCDD/Fs and PCBs in beef although one study has suggested 35 months for PCDD/Fs in 10 month old beef cattle (Thorpe et al., 2001 ) dosed over a 28 day period. However, as this is an artificial dosing study its transferability to this context is uncertain. Another study indicated 13 months for PCBs in beef (Gill et al., 1992). We also note that especially on the Aire/Ouse, several of the beef samples were taken up to half way through this indoor period. Taken together we 
suggest that the period of finishing-off cattle to market readiness is unlikely to alter dramatically the levels of PCDD/Fs and PCBs in meat observed in this study. This could only be verified by actual measurement. This suggests that the source of the elevated levels in these river systems is a historical legacy of contamination due to previous industrialisation, as well as more recent combustion activity or pollution events.

This study is the first controlled investigation into the effects of flooded river pastures on beef production. In spite of the low number of samples, it has presented robust evidence that, in catchments with a history of urbanisation and industrialisation, flooding is a mechanism for transferring PCDD/Fs and PCBs into meat and thereby into the human food chain. Across the globe there are a number of river systems where contamination of river sediments with PCDD/Fs or PCBs have been reported (Hilscherova et al., 2003; Jiamo et al., 2003; Umlauf et al., 2005). Our study indicates that within such areas, farming on flood-prone land may present an additional source of elevated PCDD/F and PCB levels in beef. In many parts of the world PCDD/F and PCB levels in soils similar to those observed in this study have been found. These occur in both more and less developed countries (e.g. China (Xiao et al., 2010; Zhang et al., 2009)). Our results indicate that, depending upon the specifics of animal husbandry (Lake et al., 2011), in such areas there is the potential for levels of PCDD/F and PCBs in beef to be close to those observed in this study.

\section{Appendix A. Supplementary data}

Supplementary data to this article can be found online at http://dx. doi.org/10.1016/j.scitotenv.2014.01.080.

\section{References}

Alcock RE, Jones KC. Dioxins in the environment: a review of trend data. Environ Sci Technol 1996;30:3133-43.

Alivernini S, Battistelli CL, Turrio-Baldassarri L. Human milk as a vector and an indicator of exposure to PCBs and PBDEs: temporal trend of samples collected in Rome. Bull Environ Contam Toxicol 2011;87:21-5.

Ball DJ, Creaser CS, Foxall CD, Lovett AA, MacGuire FAS, Patteson M. Polychlorinated biphenyls, dioxins and furans in the pontypool environment. Fourth report to Welsh Office. UK: Centre for Environmental Risk, University of East Anglia; 1993.

Bustnes JO, Moe B, Herzke D, Hanssen SA, Nordstad T, Sagerup K, et al. Strongly increasing blood concentrations of lipid-soluble organochlorines in high arctic common eiders during incubation fast. Chemosphere 2010;79:320-5.

Debier C, Chalon C, Le Bœuf BJ, de Tillesse T, Larondelle Y, Thomé JP. Mobilization of PCBs from blubber to blood in northern elephant seals (Mirounga angustirostris) during the post-weaning fast. Aquat Toxicol 2006:80:149-57.

Durand B, Dufour B, Fraisse D, Defour S, Duhem K, Le-Barillec K. Levels of PCDDs, PCDFs and dioxin-like PCBs in raw cow's milk collected in France in 2006. Chemosphere 2008;70:689-93.

European Commission. Commission Recommendation (EU) No 2011/516/EU of 23/08/2011 on the reduction of the presence of dioxins, furans and PCBs in food and feed. Off J Eur Union 2011a;L218:23.

European Commission. Regulation (EU) No 1259/2011 of 2 December 2011 amending Regulation (EC) No 1881/2006 as regards maximum levels for dioxins, dioxin-like PCBs and non dioxin-like PCBs in foodstuffs. Off J Eur Union 2011b;L320:18.

Fattore E, Vigano L, Mariani G, Guzzi A, Benfenati E, Fanelli R. Polychlorinated dibenzop-dioxins and dibenzofurans in River Po sediments. Chemosphere 2002;49:749-54.

Fernandes A, Gallani B, Gem M, White S, Rose M. Trends in the dioxin and PCB content of the UK diet. Organohalogen Compd 2004;66:2053-60.

Fernandes A, White S, Rose M. Determination of the dioxin and PCB content of animal feed samples for an EC member state collaborative study, CSL Report FD06/02; 2006.

Food Standards Agency. Dioxins and dioxin-like PCBs in the UK diet: 2001 total diet study samples. London: UK Food Standards Agency; 2003.

Foxall CD, Fernandes A, Lake IR, White S, Lovett AA, Rose M. The effects of river flooding on dioxin and PCB levels in pastureland soil, grass and cow's milk. London: Food Standards Agency; 2004.

Gill IJ, Roberts GS, Galvin JW. Management of land and livestock contaminated with polychlorinated biphenyls. Aust Vet J 1992;69:155-8.

Harrison N, Wearne S, Gem MGDM, Gleadle A, Startin J, Thorpe S, et al. Time trends in human dietary exposure to PCDDs, PCDFs and PCBs in the UK. Chemosphere 1998;37:1657-70.
Healey WB. Ingestion of soil by dairy cows. New Zealand. J Agric Res 1968;11:487-99. Hill AB. The environment and disease: association of causation? Proc R Soc Med 1965;58: 295-300.

Hilscherova K, Kurunthachalam K, Nakata H, Hanari N, Yamashita N, Bradley PW, et al. Polychlorinated dibenzo-p-dioxin and dibenzofuran concentration profiles in sediments and flood-plain soils of the Tittabawassee River, Michigan. Environ Sci Technol 2003;37: 468-74.

Jiamo F, Bixian M, Guoying S, Gan Z, Xinming W, Ping'an P, et al. Persistent organic pollutants in environment of the Pear River Delta, China: an overview. Chemosphere 2003;52: 1411-22.

Lake IR, Foxall CD, Lovett AA, Fernandes A, Dowding A, White S, et al. Effects of river flooding on PCDD/F and PCB levels in cows' milk, soil, and grass. Environ Sci Technol 2005;39:9033-8.

Lake IR, Foxall CD, Fernandes A, Lewis M, Rose M, White O, et al. Effects of river flooding on polybrominated diphenyl ether (PBDE) levels in cows' milk, soil, and grass. Environ Sci Technol 2011;45:5017-24.

Lake IR, Fernandes A, Foxall CD, Rose M, Lewis M, White O. The impact of river flooding on food produced on flood plains. London: Food Standards Agency; 2012.

Landis WG, Bryant PT. Using weight of evidence characterization and modeling to investigate the cause of the changes in pacific herring (Clupea pallasi) population dynamics in Puget sound and at cherry point, Washington. Risk Anal 2010;30:183-202.

Liem AKD, Fürst P, Rappe C. Exposure of populations to dioxins and related compounds. Food Addit Contam 2000;17:241-59.

Lignell S, Aune M, Darnerud PO, Cnattingius S, Glynn A. Persistent organochlorine and organobromine compounds in mother's milk from Sweden 1996-2006: compound-specific temporal trends. Environ Res 2009;109:760-7.

Linkov I, Loney D, Cormier S, Satterstrom FK, Bridges T. Weight-of-evidence evaluation in environmental assessment: Review of qualitative and quantitative approaches. Sci Total Environ 2009;407:5199-205.

Lorber M, Saunders P, Ferrario J, Leese W, Winters D, Cleverly D, et al. A statistical survey of dioxin-like compounds in United States pork fat. presented at Dioxin '97, the 17th International Symposium on Chlorinated Dioxins and Related Compounds, held August 25-29 at Indianapolis, USA. Organohalogen Compd 1997:32.

Ministry of Agriculture Fisheries and Food. Dioxins and PCBs in cows' milk from farms close to industrial sites: Rotherham. Food Surveillance Information Sheet; 1997.

Schecter A, Gasiewicz TA. Dioxins and health. 2nd ed. London and New York: John Wiley \& Sons; 2003.

Schuster JK, Gioia R, Moeckel C, Agarwal T, Bucheli TD, Breivik K, et al. Has the burden and distribution of PCBs and PBDEs changed in European background soils between 1998 and 2008? Implications for sources and processes. Environ Sci Technol 2011;45: 7291-7.

Shen H, Han J, Tie X, Xu W, Ren Y, Ye C. Polychlorinated dibenzo-p-dioxins/furans and polychlorinated biphenyls in human adipose tissue from Zhejiang Province, China. Chemosphere 2009;74:384-8.

Startin J, Rose M. Dioxins and dioxin-like PCBs in food. In: Schecter A, Gasiewicz TA, editors. Dioxins and Health; 2003.

Sun SJ, Kayama F, Zhao JH, Ge J, Yang YX, Fukatsu H, et al. Longitudinal increases in $\mathrm{PCDD} / \mathrm{F}$ and dl-PCB concentrations in human milk in northern China. Chemosphere $2011 ; 85: 448-53$.

Swaen G, van Amelsvoort L. A weight of evidence approach to causal inference. J Clin Epidemiol 2009;62:270-7.

Thomas GO, Sweetman AJ, Jones KC. Metabolism and body-burden of PCBs in lactating dairy cows. Chemosphere 1999;39:1533-44.

Thornton I, Abrahams P. Soil ingestion - a major pathway of heavy metals into livestock grazing contaminated land. Sci Total Environ 1983;28:287-94.

Thorpe S, Kelly M, Startin J, Harrison N, Rose M. Concentration changes for 5 PCDD/F congeners after administration in beef cattle. Chemosphere 2001:43:869-79.

Umlauf G, Bidoglio G, Christoph EH, Kampheus J, Krüger F, Landmann D, et al. The situation of PCDD/Fs and dioxin-like PCBs after the flooding of river Elbe and Mulde in 2002. Acta Hydrochim Hydrobiol 2005;33:543-54.

van den Berg M, Birnbaum L, Bosveld ATC, Brunström B, Cook P, Feeley M, et al. Toxic equivalency factors (TEFs) for PCBs, PCDDs, PCDFs for humans and wildlife. Environ Health Perspect 1998;106:775-92.

van den Berg M, Birnbaum LS, Denison M, De Vito M, Farland W, Feeley M, et al. The 2005 World Health Organization reevaluation of human and mammalian toxic equivalency factors for dioxins and dioxin-like compounds. Toxicol Sci 2006; 93:223-41.

Xiao K, Zheng M, Fang L, Yang Y. Concentrations and profiles of polychlorinated dibenzo-p-dioxins and dibenzofurans in bank soils collected from Dongting Lake, China. Bull Environ Contam Toxicol 2010;85:174-8.

Zhang H, Ni Y, Chen J, Su F, Lu X, Zhao L, et al. Polychlorinated dibenzo-p-dioxins and dibenzofurans in soils and sediments from Daliao River Basin, China. Chemosphere 2008;73:1640-8.

Zhang S, Peng P, Huang W, Li X, Zhang G. PCDD/PCDF pollution in soils and sediments from the Pearl River Delta of China. Chemosphere 2009;75:1186-95.

Zhao B, Zheng M, Jiang G. Dioxin emissions and human exposure in China: a brief history of policy and research. Environ Health Perspect 2011;119:A112-3. 